\title{
Training Requirements Of Entry Level Accountants: CA (India) vs. CPA (US)
}

Alka Arora, University of Wisconsin-Whitewater, USA

\begin{abstract}
In the accounting arena, tax returns are increasingly being outsourced to India. Tax returns that are outsourced to India are usually prepared by entry level accountants. Questions are often raised about the quality of education and training of entry level accountants in India. This article compares the training requirements and costs to become an entry level Chartered Accountant $(C A)$ in India with the training requirements and costs to become an entry level Certified Public Accountant (CPA) in the US. This topic is important because of the controversy that surrounds the quality of the training received by accountants in India who prepare tax returns for US clients. Section 7216 of the Internal Revenue Code requires written taxpayer consent before a tax return is outsourced to an overseas tax preparer. The article provides relevant information that may be shared with clients.
\end{abstract}

Keywords: Certified Public Accountant; Chartered Accountant; Outsourcing; Tax returns; Institute of Chartered Accountants of India; American Institute of Certified Public Accountants

\section{INTRODUCTION}

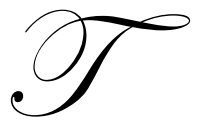

ax returns that are outsourced to India are usually prepared by entry level accountants. Since the credentials required to become a Chartered Accountant in India are significantly different from the credentials required to become a Certified Public Accountant in the US, questions are often raised about the quality of education and training of entry level accountants in India. To examine the validity of these concerns, education and training requirements to become an entry level accountant in India and the US are compared. This article limits the discussion to tax experience for entry level Chartered Accountants vs. entry level Certified Public Accountants since this is the most relevant experience in preparing individual US tax returns.

Information technology has leveled the competitive playing fields between industrial and emerging markets. Improvement in international telecommunications capacity and reduction in global telecommunications costs have increased the popularity of outsourcing. In a recent development, effective January 1, 2009, Section 7216 of the internal revenue code requires written taxpayer consent before a tax return is outsourced to an offshore preparer.

In the accounting arena, tax returns are increasingly being outsourced to India. In 2003, some 25,000 US tax returns were done in India, in 2004, the number was 100,000, and in 2005, it was roughly 400,000 (Friedman, 2007). See Table 1.

Table 1: Number of Estimated US Tax Returns prepared in India

\begin{tabular}{|c|c|}
\hline Year & Number of Returns \\
\hline 2003 & 25,000 \\
\hline 2004 & 100,000 \\
\hline 2005 & 400,000 \\
\hline 2006 & 360,000 \\
\hline Projection for 2011 & $1,600,000$ \\
\hline
\end{tabular}


Although Shamis (2008) states that "the professional on the other side of the world has a thorough understanding of the U.S. tax system and process, is of CPA quality, and is thoroughly familiar with our software," an area of concern when tax returns are outsourced is the training and skill of the overseas personnel. When hiring staff (in the US), firms thoroughly check references, educational transcripts, and also perform background checks to minimize the risk of hiring someone who lacks integrity. However, CPAs never interview the people in India that do the tax preparation work (Brody, 2004). A major benefit of outsourcing is associated with a reduction in cost. Direct cost savings occurs in the form of reducing in-house full-time or temporary staff (and the related training costs) and indirect cost savings that results from increased productivity of the core US staff (Cook et al., 2005). To address the questions about the training of entry level overseas personnel, this article compares the educational requirements and costs to become an entry level Chartered Accountant (CA) in India with the educational requirements to become an entry level Certified Public Accountant (CPA) in the US.

\section{EDUCATIONAL REQUIREMENTS}

The requirements for becoming a CA in India are significantly different from becoming a CPA in the US. One reason for this variation is the difference in philosophy of the Institute of Chartered Accountants of India (ICAI) and the American Institute of Certified Public Accountants (AICPA). While the CA program outlined by the ICAI emphasizes practical training, the AICPA stresses classroom education. See Table 2.

Table 2: Educational Requirements for becoming a CA versus a CPA

\begin{tabular}{|c|c|c|}
\hline & Requirements for becoming a CA - India & Requirements for becoming a CPA - US \\
\hline High School & $\begin{array}{l}\text { 1. Pass Grade } 10 \\
\text { 2. (i) Register with the Board of Studies for the } \\
\text { Common Proficiency Test, and } \\
\text { simultaneously } \\
\text { (ii) Complete grade } 11 \text {, grade } 12 \text { and take the } \\
\text { Senior Secondary examination or an } \\
\text { equivalent exam } \\
\text { 3. Pass the Common Proficiency Test }\end{array}$ & -No pre-requisites \\
\hline 150-semester hours & Not required & $\begin{array}{l}\text { In most states, } 150 \text { semester hours of coursework } \\
\text { at an accredited university }\end{array}$ \\
\hline Practical training & $\begin{array}{l}\text { - Three and half years of article / audit Training } \\
\text { - } 100 \text { hours of Information Technology Training }\end{array}$ & Internship (Optional) \\
\hline Licensing Exam & $\begin{array}{l}\text { Two parts: } \\
\text { I. Professional Competency Exam } \\
\text { II. Final Exam }\end{array}$ & $\begin{array}{l}\text { Four sections: } \\
\text {-Auditing and Attestation (AUD) } \\
\text {-Business Environment and Concepts (BEC) } \\
\text {-Financial Accounting and Reporting (FAR) } \\
\text {-Regulation (REG) }\end{array}$ \\
\hline Review Courses & $\begin{array}{l}\text { - Required self-study course for Common } \\
\text { Proficiency Test, Professional Competency Exam } \\
\text { and Final Exam provided by the Institute of } \\
\text { Chartered Accountants of India } \\
\text { - General Management and Communications } \\
\text { course }\end{array}$ & -CPA Review Course (Optional) \\
\hline $\begin{array}{l}\text { Work Experience } \\
\text { Necessary to obtain } \\
\text { certificate to practice }\end{array}$ & Not Required & $\begin{array}{l}\text {-At least one year of public accounting } \\
\text { experience or its equivalent as determined by the } \\
\text { board }\end{array}$ \\
\hline $\begin{array}{l}\text { Ethics Exam } \\
\text { to obtain certificate } \\
\text { to practice }\end{array}$ & Not Required & -Pass the Online Ethics Exam \\
\hline
\end{tabular}

\section{High School}

After passing the tenth grade, a high school student in India, who plans to pursue a career in accounting, registers with the Board of Studies of the Institute of Chartered Accountants of India (ICAI) for the Common 
Proficiency Test. This test is administered to registered students after they have successfully completed grade twelve. $^{1}$

In the US, at the high school level there are no pre-requisites which a student needs to complete in order to be eligible to join the accounting profession. The AICPA has budgeted $\$ 25$ million for a marketing program which aims to attract intelligent and hard-working students to the accounting profession. ${ }^{2}$ Also, in Wisconsin, the High School Speaker Program organized by the Wisconsin Institute of Certified Public Accountants is designed to attract these students to become accountants.

\section{0-semester hours of education}

To qualify as a CA in India, students are not required to attain either a bachelors or master's degree. There is no requirement for completing 150 -semester hours of education. However, most students who choose the accounting profession take college-level courses over a period of five years.

Most states require all students taking the CPA exam to complete 150-semester hours of education, which includes many accounting courses, to earn either a bachelors or a graduate degree. Specific conditions in obtaining the 150-semester hours of education are outlined by the National Association of State Boards of Accountancy. ${ }^{3}$ CPA exam candidates who have completed educational requirements at institutions outside the US need to have their credentials evaluated by any member organization of the National Association of Credential Evaluation Services (NACES). ${ }^{4}$

\section{Practical Training}

In India, high school students study introductory accounting concepts to prepare for the Common Proficiency Test. After passing this test, students register for practical training as article/audit clerk and register for 100 hours of Information Technology Training. ${ }^{5}$ As article/audit clerks, students work with a practicing Chartered Accountant for a period of three and a half years. During this period, students are expected to work at least 40 hours a week doing tax returns and/or audit assignments. The hours of work are determined by the practicing accountant and are based on needs of the client. It is not uncommon for article/audit clerks to work 80-100 hours a week during the busy season. Simultaneously, students are studying for the two-part CA exam which is similar to the CPA exam.

The primary purpose of the article/audit training is to enable students to acquire the skills and expertise required by members of the accounting profession in India. The Chartered Accountant is required to assign progressively more difficult tax returns to article/audit clerks commensurate with the expanding abilities of the trainees. After the article/audit clerk masters a number of 'core' assignments, $s /$ he is allocated further assignments that broaden the trainee's experience, expand their technical skills, or enhance their supervisory skills. Using computer software, a first-year article clerk in the tax department of a practicing accountant may compile tax data of a US client; a second-year article clerk may prepare the tax return; and a third-year article clerk may review the tax return. ${ }^{6}$ A third-year article clerk is often required to establish client contact. About three months into the

\footnotetext{
${ }^{1}$ Students in India have a choice of completing Grade 11 and Grade 12 either in the high school or in a college.

$2 \mathrm{http} / / /$ www.wicpa.org/Student_Teacher/speakers.htm

3 http://www.nasba.org/nasbaweb/NASBAWeb.nsf/wpecer?openform\&stateabbrev=WI

${ }^{4}$ In addition to having their credentials evaluated, the candidate needs to earn credit for one course of income tax and one course of business law from a four- year US institution with regional accreditation. Accountants in India who prepare tax returns for US residents are not required to have their credentials evaluated nor earn credit for one course of income tax and one course of business law from a four-year US institution with regional accreditation.

${ }_{6}^{5} \mathrm{http} / / / \mathrm{www}$.icai.org/resource file/15238trai guide.pdf

6 As an example, for simple returns that are outsourced to India, a year 1 article clerk (a recent high school graduate) may compile tax data to prepare the return, a year 2 article clerk may prepare the return, and a year 3 article clerk may review the return before the return is transmitted to the CPA firm in the US. The same return in the US is likely to be prepared by an entry level accountant. If the cost to the firm of preparing a simple return in the US is $\$ 150$, the cost savings for the CPA firm are phenomenal: during the training period, an article clerk is paid a monthly stipend of about $\$ 12.50-\$ 25.00$ in the first year to approximately $\$ 25.00$ - $\$ 37.50$ in the third year $(\$ 1=$ Rupees 40$)$.
} 
article/audit training, the high school graduate is required to register for 100 hours of Information Technology Training. This is a 20-day program with training for five hours per day. The training is administered by the regional offices of the ICAI.

In the US, since most of the training is classroom education in college, students frequently work as interns. Many college juniors and seniors have a paid internship provided by CPA firms, industry, or government. For example, during the spring semester these students might register for six hours of internship training followed by six-semester hours of college courses. Internships provide a way to allow US accounting students to participate in actual audit and tax compliance engagements and meet a variety of professionals, both internally and externally. ${ }^{7}$ In general, student interns are not expected to either assume the responsibility of an entry-level accountant or to work in a supervisory capacity.

\section{Licensing Exams}

In India, the CA exam is administered in two parts - Professional Competency Exam and Final Exam. The Professional Competency Exam is administered to students who have completed between 15 and18 months of article/audit training. ${ }^{8}$ The subject areas covered by this exam are: Auditing and Assurance, Ethics and Communication, Cost Accounting and Financial Management, Information Technology and Strategic Management, Law, Advanced Accounting, and Taxation. The Final Exam is administered to students after they complete three and half years of article/audit training and pass the Professional Competency Exam. This exam covers the following areas: Advanced Auditing and Professional Ethics, Corporate and Allied Laws, Information Systems Control and Audit, Financial Reporting, Advanced Management Accounting, Strategic Financial Management, Direct Tax Laws, and Indirect Tax Laws. Neither part of the CA exam is computerized.

The CPA is a four-part computerized exam. The four sections are: Auditing and Attestation (AUD), Business Environment and Concepts (BEC), Financial Accounting and Reporting (FAR), and Regulation (REG). Students may take the sections individually and in any order. They have 18 months to pass all four parts of the CPA exam. The first-time pass rate for both the CA and the CPA exams are relatively low.

\section{Review Courses}

After passing the first part of the CA exam (Professional Competency Exam), accounting students in India are required to complete a General Management and Communications Skills Course. To help students prepare for the Common Proficiency Test, the Professional Competency Exam, and the Final Exam, the Board of Studies of the ICAI provides study material to the students. Students are also encouraged to attend review courses offered by institutions that are accredited by the Board of Studies of the ICAI.

The 150-semester hours of education are designed to help accounting students in the US prepare for the CPA exam. Often, students voluntarily register for private CPA review courses to prepare for the CPA exam. The CPA review course is not accredited either by the AICPA or by any college or university.

\section{Work Experience Necessary to obtain certificate to practice}

After passing both parts of the licensing exam, students in India are not expected to acquire any work experience to obtain the certificate to practice as a CA. The article/audit experience is deemed sufficient work experience. In several states in the US, to obtain a CPA license, students who have passed all parts of the CPA exam need at least one year of public accounting experience or its equivalent.

\footnotetext{
${ }^{7}$ Student interns receive three semester hours of credit for a summer internship and six semester hours of credit for spring internships.

${ }^{8}$ Specifically a student registers for the exam after completing not less than fifteen months of practical training, three months prior to the first day of the month in which examination is held. http://www.icai.org
} 


\section{Online Ethics Exam}

In several states in the US, to obtain a CPA license, students who have passed both parts of the CPA exam and acquired the necessary work experience are required to pass an ethics exam online. There is no such requirement in India.

\section{COST OF EDUCATION}

Brody et al. (2004) states that outsourcing tax returns is advantageous for US accounting firms because the standard of living and the wage base in India are much lower than in the United States; therefore, the labor cost for accounting professionals is also much lower. This study contends that one reason for the differential is the expenditure incurred for the educational requirements necessary to obtain the professional certification to practice as a CA versus the cost of the education requirements necessary to obtain the professional certification to practice as a CPA. See Table 3.

Table 3: Cost of Becoming a CA versus a CPA

\begin{tabular}{|c|c|c|c|}
\hline . & \multicolumn{2}{|c|}{ CA - India } & \multirow{2}{*}{$\begin{array}{c}\text { CPA - US } \\
\text { In US Dollars }\end{array}$} \\
\hline & $\begin{array}{c}\text { In Indian Rupees } \\
\text { (Rs.) }\end{array}$ & $\begin{array}{c}\text { In US Dollars } \\
(\$ 1=\text { Rs. 40) }\end{array}$ & \\
\hline \multicolumn{4}{|l|}{ 150-semester hours } \\
\hline Tuition & $100,000.00^{*}$ & $2,500.00$ & $\$ 31,000.00$ \\
\hline Room and Boarding & & & $24,290.00^{*}$ \\
\hline \multicolumn{4}{|l|}{ Registration Fee ICAI } \\
\hline Common Proficiency Test & $3,500.00$ & 87.50 & \\
\hline Professional Competency Exam & $5,500.00$ & 137.50 & \\
\hline Final Exam & $8,500.00$ & 212.50 & \\
\hline $\begin{array}{l}100 \text { hours of Information Technology } \\
\text { Training }\end{array}$ & $2,000.00$ & 50.00 & \\
\hline $\begin{array}{l}\text { General Management and Communications } \\
\text { course }\end{array}$ & $4,000.00$ & 100.00 & \\
\hline CPA Review Course & & & $2,000.00$ \\
\hline \multicolumn{4}{|l|}{ Exam Fee } \\
\hline Common Proficiency Test & 400.00 & 10.00 & \\
\hline Professional Competency Exam & $1,250.00$ & 31.25 & \\
\hline Final Exam & $1,750.00$ & 43.75 & \\
\hline AUD & & & 226.28 \\
\hline BEC & & & 178.58 \\
\hline FAR & & & 214.35 \\
\hline REG & & & 190.50 \\
\hline Credential Fee & $1,700.00$ & 42.50 & 59.00 \\
\hline Ethics Exam Fee & & & 57.00 \\
\hline Total & Rs. 128,600 & $\$ 3,215.00$ & $\$ 58,215.71$ \\
\hline
\end{tabular}

*Discretionary Expenses

Students who choose the accounting profession in India often attend five years of college after they matriculate from school in the tenth grade. The average cost of admission, tuition, and computer lab fees over the five-year period is $\$ 2,500$. These costs are associated with seeking a bachelor's degree and may be classified as "discretionary costs", not "relevant costs." Students who pursue the accounting career in India generally live at home with their parents. These living costs may be classified as "opportunity costs" even though they are not "outlay costs." Since opportunity costs vary in accordance with individual choices, a cost for room and boarding has been excluded for students who seek to become a CA in India. To become a CA, accounting students in India are required to register and pass three major exams - the Common Proficiency Exam, the Professional Competency Exam, and the Final Exam. The registration fees charged by ICAI for the Common Proficiency Exam, the Professional Competency Exam, and the Final Exam are \$87.50, \$137.50, and \$212.50, respectively. The exam fees 
charged by ICAI for the Common Proficiency Exam, the Professional Competency Exam, and the Final Exam are $\$ 10.00, \$ 31.25$, and $\$ 43.75$, respectively. Students undergo Informational Technology Training at a cost of $\$ 50$ and complete the General Communications Course at a cost of $\$ 100$. The credential fee to obtain the certificate to practice as a CA is $\$ 42.50$. Therefore, the total cost to become a CA is $\$ 715$.

To satisfy the 150-semester hour requirement, a student in the US attends an accredited college or university for an approximate period of five years. At the University of Wisconsin-Whitewater, the cost of in-state tuition for a period of five years is about $\$ 31,000$. Most students live at Whitewater and the cost of room and board over the period of five years is about $\$ 24,290$. A reasonable number of students registered for the Accounting program in Whitewater live at home to save money while pursuing their academic degrees. Others choose to live off campus, while most freshmen and sophomores live in the dorms. Thus, costs of room and board may be classified as "discretionary costs" associated with living, not "relevant costs" associated with an academic degree. Students who take the CPA exam often register for a review course to prepare for the test. The cost of the most popular review course is about $\$ 2,000$ and the cost of taking the four parts of the CPA exam is $\$ 809.71$. The cost of the online ethics exam is $\$ 57$ and the credential fee is $\$ 59$.

\section{COST AS A PERCENTAGE OF PER CAPITA GROSS DOMESTIC PRODUCT}

The gross domestic product (GDP) is a basic measure of an economy's economic performance. It represents the market value of all final goods and services made within the borders of a nation in a year. The percapita GDP is equal to the country's GDP divided by the total number of people in the country. See Table 4.

Table 4: Cost of Becoming a CA vs. CPA as a Percentage of GDP per Capita

\begin{tabular}{|l|c|c|}
\hline & India & United States \\
\hline Cost excluding Discretionary Expenses (Per Table 3) & $\mathbf{\$ 7 1 5 . 0 0}$ & $\mathbf{\$ 2 7 , 5 1 2 . 7 1}$ \\
\hline Per Capita GDP & $\$ 2,800$ & $\$ 47,000$ \\
\hline$\%$ cost to Per Capita GDP & $25.56 \%$ & $58.54 \%$ \\
\hline
\end{tabular}

Source: http://www.investorwords.com/6827/GDP_per_capita.html

To draw a meaningful comparison between the cost of becoming a CA in India and the cost of becoming a CPA in the US, Table 4 presents the cost of education in each country, excluding discretionary expenses and opportunity costs, as a percentage of the per-capita GDP for the respective countries. In India, the cost of becoming a CA is $25.56 \%$ of the per-capita GDP, while in the US the cost of becoming a CPA is $58.54 \%$ of the per-capita GDP.

\section{CONCLUSION}

CPA firms that outsource returns to India may reduce client concerns about outsourcing individual tax returns to India by presenting the educational competency of the offshore tax preparer. In India, entry-level accountants are required to acquire at least three years of work experience and pass three levels of exams before they become a CA. In contrast, to practice as a CPA in the US, most entry-level accountants are required to complete 150 credit hours of undergraduate course work, pass four parts of the CPA exam and, in many states, obtain at least one year of public accounting experience or its equivalent. While the cost of becoming a CA in India is lower than the cost of becoming a CPA in the US, the licensing exams in both countries are comprehensive and rigorous.

On a cautionary note, clients need to: 1) know that the International Qualifications Appraisal Board (IQAB), which represents NASBA and the AICPA in entering into reciprocity agreements with professionals in other countries, has not granted reciprocity to Indian CAs because Indian CAs do not meet equivalency standards and 2) recognize the inherent risks associated with the electronic transmission of confidential data to an overseas location. 


\section{AUTHOR INFORMATION}

Alka Arora is the C.A Black Professor of Accounting and the Chair of the Department of Accounting at the University of Wisconsin-Whitewater. She has served on the Careers Committee of the Wisconsin Institute of Certified Public Accountants since 1998. E-mail: aroraa@uww.edu.

\section{REFERENCES}

1. Anonymous. "Stay under the Radar!" Accounting Technology: Tune Up, Take Off! The Year in Tax Jan. 2009: 11-12.

2. Blackman, Andrew B, Mitchell Freedman, and John Levy. "Outsourcing by CPAs: Are We a Business or a Profession?" The CPA Journal 74.5 (May 2004): 6-9.

3. Brody, Richard G, Mary J Miller, and Michael J Rolleri. "Outsourcing Income Tax Returns to India: Legal, Ethical, and Professional Issues." CPA Journal 74.12 (Dec. 2004): 12-15.

4. "Certified Public Accountant - Credentialing." State of Wisconsin: Department of Regulation and Licencing. 19 June 2007. State of Wisconsin: Department of Regulation and Licencing. 29 Mar. 2008 http://drl.wi.gov/prof/acct/cred.htm>.

5. Cook, Ellen D, Sarah E Hazelwood, and Anita C Hazelwood. "Outsourcing Tax Returns Raises Legal and Ethical Concerns." Practical Tax Strategies 75.2 (Aug. 2005): 68-74.

6. $\quad$ "Country Comparisons:: GDP per Capita (PPP)." The World Factbook. 2 July 2009. Central Intelligence Agency. 2 July 2009 <http://www.cia.gov/library/publications/the-world-factbook/rankorder/ 2004rank.html>.

7. $\quad$ Davis, Riccardo A. "Outsourcing Sparks Returns." Accounting Technology 21.1 (Jan. 2005): 37-43.

8. $\quad$ "Estimate Your Cost of Attending UW-Whitewater." University of Wisconsin-Whitewater. Current. U of Wisconsin-Whitewater. 29 Mar. 2008 <https://uwwcost.uww.edu/>.

9. "Exams, CPA Exam, Wisconsin." National Association of State Boards of Accountancy. Current. National Assn. of State Boards of Accountancy. 29 Mar. 2008 〈http://www.nasba.org/nasbaweb/NASBAWeb.nsf/WPEMP>.

10. Friedman, Thomas L. The World Is Flat 3.0: A Brief History of the Twenty-first Century. New York: Farrar, Straus, Giroux, 2007.

11. Haylock, John. "A Truly Flat World." Chartered Accountants Journal of New Zealand. 86.9 (Oct. 2007): $62+$.

12. $\quad$ Mintz, Steve. "The Ethical Dilemmas of Outsourcing." The CPA Journal 74.3 (Mar. 2004): 6-10.

13. Myers, Elwin. "Outsourcing CPA Work Is Going a Bit Too Far." Corpus Christi Caller - Times 18 July 2005: D8.

14. $\quad$ "OffshoringTax Returns Preparation to India." Business Wire The Global Leader in News Distribution. Nov. 2006. Research and Markets. 17 Mar. 2008 <http://http://www.researchandmarkets.com/ reports/c46387>.

15. $\quad$ Pink, Daniel H. "Revenge of the Right Brain." PM. Public Management 89.6 (July 2007): 10-15.

16. "Rank Order GDP - Purchasing Power Parity." The World Fact Book. 21 Aug. 2008. Central Intelligence Agency. 23 Aug. 2008 <https://www.cia.gov/library/publications/the-world-factbook/rankorder/ 2001rank.html>.

17. Robertson, Jesse, et al. "Offshore Outsourcing of Tax-Return Preparation." The CPA Journal. 75.6 (June 2005): 54-58.

18. "Section 7216 Updated Rules for Tax Preparers (Updated 12/18/2008)." Internal Revenue Service: US Department of Treasury. 19 Dec. 2008. Internal Revenue Service: US Department of Treasury. 7 July 2009 〈http://www.irs.gov/efile/article/0,id=188390,00.html>.

19. Shamis, Gary S. "Should Your Firm Have a Global Strategy?" CPA Practice Management Forum 4.6 (2008): 14-16.

20. $\quad$ "Students." Institute of Chartered Accountants of India. Current. Inst. of Chartered Accountants of India. 29 Mar. $2008<$ http://icai.org/>.

21. Training Guide. 14 May 2007. The Inst. of Chartered Accountants of India. 6 July 2009 $\langle$ http://www.icai.org/resource_file/15238trai_guide.pdf $>$. 
22. The Uniform CPA Examination. AICPA, NASBA, and Boards of Accountancy. 29 Mar. 2008 <http://www.cpa-exam.org/>.

\section{NOTES}

